\title{
THE IMPACT OF GOOGLE EDUCATION SUITE AMIDST THE PANDEMIC: THE NEW NORMAL APPROACH
}

H.E. Ambassador Dr. Froilan D. Mobo

Associate Professor II / Assistant Director

Department of Research and Development

Philippine Merchant Marine Academy

Philippines

\begin{abstract}
The Education system in the Philippines was greatly affected by the deadly pandemic - Novel Corona Virus which transcends all our sectors into highly ICT Based enabled sector by using different technological platforms just to continue in their workforce. As part of the challenge in the new normal we are facing right now is the availability to double the services like the increase of bandwidth requirements because of the Distance Education being implemented in all higher education. The researcher is proposing a study to minimize network traffic and slowdown of internet connections and video conferencing by using an alternative platform which can minimize the usage of internet bandwidth. In terms of the video-conferencing classroom platform, it is highly recommended to use another source or tools that can be used in online learning, which is by using the upgraded requirements.
\end{abstract}

Keywords: Distance Education, ICT, Google Education Suite

\section{INTRODUCTION}

The Education system in the Philippines was greatly affected by the deadly pandemic - Novel Corona Virus which transcends all our sectors into highly ICT Based enabled sector by using different technological platforms just to continue in their workforce. Internet bandwidth is the most common issues encountered by most students using asynchronous distance education right now. Other students are complaining that their interconnectivity is getting slower every time they met in their online classes. Google Suite Education is a powerful Web 3.0 collaboration and communicating tool that can strengthen Online Learning Education in supporting students to enrich specific 21st century skills which may includes effective self-directed learning skills, problem based solving and critical thinking skills, (Sriphong, 2019)The government doesn't allow the educational sector to conduct face to face mode and as part of the challenge in the new normal we are facing right now is the availability to double the services like the increase of bandwidth requirements because of the Distance Education being implemented in all higher education. Online Education using G-Suite for Education shows students could follow online learning strategies, in the delivery of the course material and or assessment of learning outcomes in every module, (Alsheikh-Ali et al., 2011).The researcher is proposing a study to minimize network traffic and slowdown of internet connections and video conferencing by using an alternative platform which can minimize the usage of internet bandwidth like Google 
Suite which emerge significantly mostly from work from home set up because the licensing is free and can lessen bandwidth and network issues also unlike Zoom applications it requires more bandwidth usage.

\section{OBJECTIVES}

1. To determine which is better zoom or Google suite in terms of the following:
1.1. Speed
1.2. Security
1.3. Reliability
1.4. Setup
1.5. Pricing

2. To determine the level of the perceptions of Zoom and Google Suite.

\section{METHODOLOGY}

The Researcher had used a qualitative research design and had distributed a questionnaire using google form in private and public institution as well as industry sector. Respondents of the study were the selected employees and academicians in selected private and public institution. Data Analysis was conducted right after the Online Google Survey, this is to check results of the study.

\section{RESULTS AND DISCUSSIONS}

Determine which is better zoom or Google suite:

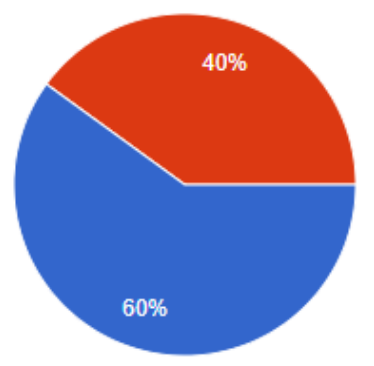

ZOOM APPLICATION

GOOGLE SUITE

Figure 1: it only shows that $60 \%$ is using Google Suite rather $40 \%$ are using Zoom Application in Online Classes because they consider the performance and it is cheaper comparing to zoom in terms of pricing.

In terms of preferences using Zoom: 


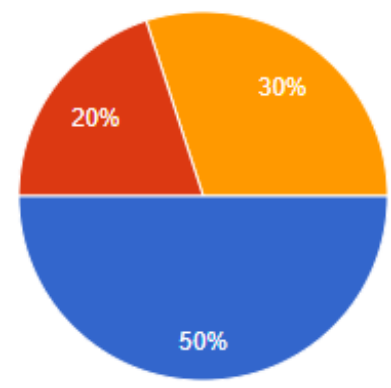

Figure 2: Shows that there are 50\% who suggested that zoom is more faster rather than Google Suite. In terms of Security there are $20 \%$ and $30 \%$ reliability are the most preferred choices of the users using Zoom Application.

In terms of preferences using Google Suite:

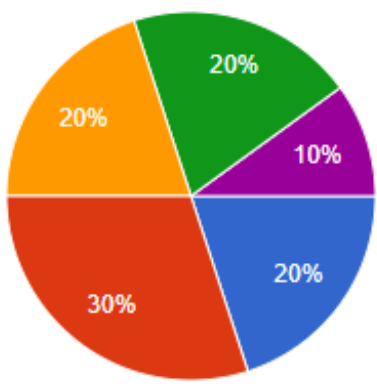

Figure 3. Shows that that there are 30\% who selected Google suite as a secured platform rather than Zoom while $20 \%$ also selected in terms of security, reliability and Setup and in terms of pricing it is $10 \%$ because you can use it for free.

\section{CONCLUSIONS AND RECOMMENDATIONS}

Based on the concluded study majority of the users preferred to use Google Suite, specifically using Google meet in terms of the Speed, Security, Reliability, Setup, and Pricing. In which Google Suite can be used in many ways for document uploading, calendar usage, and most likely linking the schedule of classes in calendar connecting to google meet. Other results also showed that using Google Suite for Education in learning was found to be more knowledgeable in terms of valuing the role of ICT., (Insani et al., 2020). Google meet can only use a small amount of bandwidth during online video conferencing class and it saves more bandwidth speed.

It is highly recommended to use Google Suite rather than Zoom Applications because of its performances in terms of the following Speed, Security, Reliability, Setup, and Pricing. Teachers and students in other university also desires to work collaboratively using interactive and easy-to-manage tools for improving their learning process using Google Suite., (Mahapatra et al., 2017, p. 277) Further studies are really needed in order to perfect the whole processes.

Received 8 February 2021; Received in revised form I5 February 20Z1; Accepted 25 February 2021; 
Other users show their enthusiasm of learning the 21st century skills using Google suite., (Wijayanti et al., 2020).

\section{REFERENCES}

Alsheikh-Ali, A. A., Qureshi, W., Al-Mallah, M. H., \& Ioannidis, J. P. A. (2011). Public Availability of Published Research Data in High-Impact Journals. PLoS ONE, 6(9), e24357. https://doi.org/10.1371/journal.pone.0024357

Sriphong, L. (2019). Innovative problem-based learning integrated with G suite for education. Proceedings of the 10th International Conference on E-Education, E-Business, EManagement and E-Learning - IC4E '19, ACM Digital Library. https://doi.org/10.1145/3306500.3306546

Insani, K., Suratno, \& Farisi, I. (2020). ICT literacy with google suite for education (GSFE) in junior high school with different academic abilities. Journal of Physics: Conference Series, 1563, 012058. https://doi.org/10.1088/1742-6596/1563/1/012058

Romero, E., Artal-Sevil, J. S., Mir, J. M., \& Artacho, J. M. (2018). IMPROVING LEARNING THROUGH G SUITE FOR EDUCATION. USE OF ‘GOOGLE UNIVERSE’ APPS IN THE CLASSROOM. INTED2018 Proceedings, 0. https://doi.org/10.21125/inted.2018.1840

Wijayanti, S., Kunto Aribowo, E., Setyandari, A., Nugroho Aji, W., Pebryawan, K., \& Tasari, T. (2020). GOOGLE SUITE FOR EDUCATION TRAINING FOR 21ST CENTURY LEARNING IN SMA NEGERI 1 JATINOM. PICS-J: Pasundan International of Community Service Journal, 2, 0. https://doi.org/10.23969/pics.v2i2.3389 